河道 - 貯水池系の洪水伝播解析 Analys is of Flood Propagation in Channel-Reservoir System

$\begin{array}{lllllll}\text { 財団法人 電力中央研究所 } & \text { 正 } & \text { 員 } & \text { 河 } & \text { 西基 } \\ \text { 財団法人 } & \text { 電力中央研究所 } & \text { 正 員 } & \text { 白 } & \text { 砂 } & \text { 孝 } & \text { 夫 }\end{array}$

1. はじめに

近年, 河川域周辺における都市化の進行は著しく,より細密な洪水放流操作方法の確立あるいはダムから の急激な洪水放流に対する下流河川の警報体制の整備などが緊要な課題となっている。このため，複雑な河 道，境界条件等が多く含まれるダム下流河川における洪水伝播現象を解明し，さらに河道・貯水池系を総合 的に洪水追跡し得る解析システムとして体系化するてとが今日的に重要と思われる。

そてで上述のような視点に立って，本報告においては，先ずドライ・ベッド水路あるいはダム（堰）・貯 水池などが点在している複䧴な河道区間において洪水が段波状を呈して流下する現象を取扱らてととし，乙 のよらな問題に対しても合理的な洪水追跡を実行し得る特性曲線法に基づく解析モデルを作成した。特に; 特性曲線法において特性曲線網の乱れに起因する数值解析上の困難さを回避する為に通常よく用いられてい る波速の内㧌補間に基つく特性曲線網の整斉手法がドライ・ベッド水路上の段波現象に対しては不合理なて とが明らかとなり，ての種の問題にも適するょらな波速の外挿補間に基づく整斉手法を導入した解析手法を 新たに提案した。 解析モデルの妥当性を検証した。

\title{
2. 解析モデルの内容
}

本報告においては，一次元漸変不定流の基礎方程式を段波解析に適用するに際して，特性曲線法に基ゔく 数值解析を用いているが, これらの解析手法の概略を以下に述べる。

2.1 基礎方程式と特性方程式

まず基䃈方程式としては，台形断面水路を対象として水路幅の変化を陽に考慮した次式を用いる。

[連続の式] $: \frac{\partial \mathrm{h}}{\partial \mathrm{t}}+\mathrm{v} \frac{\partial_{\mathrm{h}}}{\partial_{\mathrm{x}}}+\xi \mathrm{h} \frac{\partial_{\mathrm{V}}}{\partial_{\mathrm{x}}}=-\frac{\eta}{\mathrm{T}} \mathrm{hv}$

[運動量方程式] : $\xi \frac{\partial \mathrm{v}}{\partial \mathrm{t}}+\boldsymbol{\xi} \cdot \mathrm{v} \frac{\partial_{\mathrm{V}}}{\partial_{\mathrm{X}}}+\mathrm{g} \xi \cos \theta \frac{\partial \mathrm{h}}{\partial_{\mathrm{X}}}=\frac{\mathrm{g}}{\mathrm{T}}\left\{\sin \theta \cdot \mathrm{B}_{\mathrm{o}}-\frac{\eta}{2} \cos \theta \cdot \mathrm{h}+\sin \eta_{\theta} \cdot \mathrm{h}\right\}-\frac{1}{\mathrm{~T}}\left\{\mathrm{~B}_{\mathrm{o}}+\cos \eta_{\theta} \cdot \mathrm{sh}\right\}\left(\frac{\tau_{\mathrm{o}}}{\rho_{\mathrm{h}}}\right) \cdots \cdots(2)$

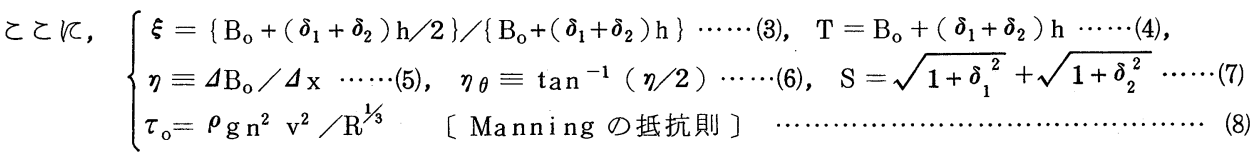

$\mathrm{h}$ : 水染, $\mathrm{v}$ : 断面平均流速, $\mathrm{x}$ : 距離, $\mathrm{t}$ : 時間, $\mathrm{g}$ : 重力加速度, $\tau_{\mathrm{o}}$ : 摩擦応力, $\rho$ : 水の密度, $\mathrm{B}_{\mathrm{o}}$ : 水路床幅, $\delta_{1}, \delta_{2}$ : 水路側壁の傾き, $\theta$ : 水路床勾配, $\mathrm{n}$ : 粗度係数, $\mathrm{R}$ : 径梁であり, 上式から次の特性方 程式が導かれる。ただし，簡単のために $\sin \theta \doteqdot \theta, \sin \eta_{\theta} \doteqdot \eta / 2$ 亿近似でをるとして記述する。

$\left\{\begin{array}{l}\mathrm{dx} / \mathrm{d} \mathrm{t}=\mathrm{v} \pm \sqrt{\xi \mathrm{gh}} \quad\left(\equiv \mathrm{w}^{+}, \mathrm{w}^{-}\right) \\ \mathrm{dv} \pm \sqrt{\frac{\mathrm{g}}{\xi \mathrm{h}}} \mathrm{dh}=\frac{1}{\mathrm{~T}}\left[\eta \mathrm{hv}\left\{\frac{\mathrm{v}}{\xi \mathrm{h}} \mp \sqrt{\frac{\mathrm{g}}{\xi \mathrm{h}}}\right\}-\frac{\eta}{\xi} \mathrm{v}^{2}+\frac{\mathrm{gB}}{\xi} \theta-\left(\frac{\tau_{\mathrm{o}}}{\rho \xi}\right)\left\{\frac{\mathrm{B}_{\mathrm{o}}}{\mathrm{h}}+\mathrm{S}\right\}\right] \mathrm{dt}\end{array}\right.$

こてに，上式におらて複号は同順であり，(9)式は波速 $\omega\left(\mathrm{x} \sim \mathrm{t}\right.$ 平面での特性曲線 $\mathrm{c}^{+}$と $\left.\mathrm{c}^{-}\right)$を表わす。

2.2 特性曲線網の整斉

特性曲線法においてい，特性曲線網の乱九に起因する数値解析上の困難さを回避するために，(9)式で与え られる波速に関して図ー1aに示されるよらな内㨉補間に基づを規則的な特性曲線格子網を構成する整斉手 
法が通常よく導入されている。例えば, 上流側から下流 側へ向ら特性曲線 $\mathrm{c}^{+}$亿関しては, 固定の未知格子点 $\mathrm{P}$ 亿 到達するよら飞移動させた既知点 $I\left(X_{I}, t_{j}\right)$ の 座標 位置を次式から求めるととがでをる。

$$
\mathrm{X}_{\mathrm{I}}=\frac{\mathrm{X}_{\mathrm{P}}+\left(\omega_{\mathrm{c}}^{+} \cdot \mathrm{X}_{\mathrm{A}}-\omega_{\mathrm{A}}^{+} \cdot \mathrm{X}_{\mathrm{c}}\right) \Delta \mathrm{t} / \Delta \mathrm{X}}{\left(\omega_{\mathrm{c}}^{+}-\omega_{\mathrm{A}}^{+}\right) \Delta \mathrm{t} / \Delta \mathrm{X}+1}
$$

こてK, 下添字壮各格子点位置を示し, また $\Delta x / \Delta \mathrm{t}$ は次式の C.F.L.の安定条件

$$
\Delta \mathrm{t} / \Delta \mathrm{x} \leq 1 /(\mathrm{v}+\sqrt{\xi \mathrm{gh}})
$$

を常に满足するように自動的に選ばれているすのとする。

しかしながら，本報告でも対象としているドライ・ベ ッド水路上の段波現象のような場合においては, 流れ先 端部の流況は急峻かつ複雑となって数学的特異点を伴う とされており ${ }^{5)}$ 数值解析上において子困難な問題が多い。 ての場合, 上述の内㨉補間飞基づく特性曲線網の整斉を 導入し泛手法を用的る際飞る，次のよらな数值解析上の 不合理を生じるととが示される。すなわち，図ー1aを参

(a) 内淿補間

(従来の方法：通常河川)

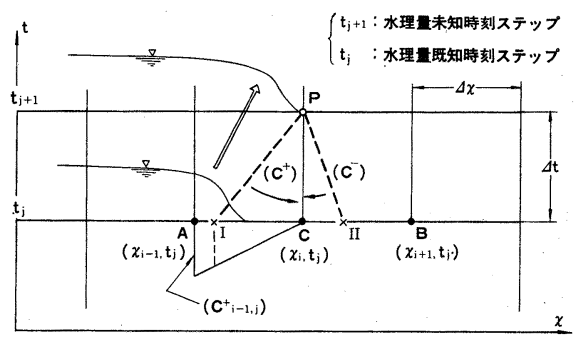

(b) 外㨀補間

(本研究:ドライ・ベッド水路)

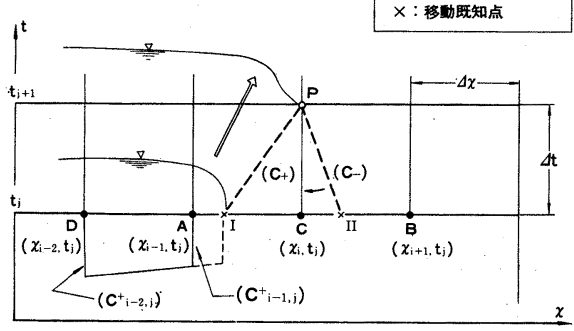

図一 1 特性曲線網の整斉 照して, 既知時刻ステップ $\mathrm{t}$ 亿おいて段波先端が格子点 $\mathrm{A}$ で既に到達している時, $\mathrm{A}$ 点と段波未到達の格 子点 $\mathrm{C}$ との間での波速の内挿補間関係を用いて未知点 $\mathrm{P}$ 亿到る移動既知点 I の座標位置を(11)式から求めると, $\omega_{c}^{+}=0$ であるから $\mathrm{X}_{\mathrm{I}} \rightarrow \mathrm{X}_{\mathrm{P}}\left(=\mathrm{X}_{\mathrm{c}}\right)$ となる。したがって, 移動既知点 $\mathrm{I}$ は II と共に必ず格子点 $\mathrm{C}$ と一致せざ るを得ず, ての $\mathrm{C}$ 点においては段波未到達のために各水理量の值がゼロであるてとから，結果的に段波が未 知点 $\mathrm{P}$ 亿到達するととは理論上あり得ないてとになってしまう。

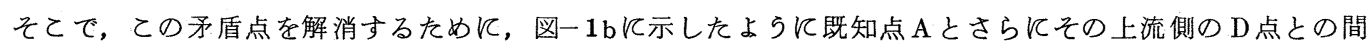
で波速を外挿補間させるととにょり移動既知点 I の座標位置を決定する整斉手法を新をに導入した。2 には, ての結果求められる移動既知点 I 亿おいて段波の先端が形成されていると解釈するとともでき, 急峻 な波先をるつ段波の特徴が比較的よく表現された形式となっている。また，具体的には(11)式において下添字 を $\mathrm{A} \rightarrow \mathrm{D}, \mathrm{C} \rightarrow \mathrm{A}$ と変換するととにより図一 $1 \mathrm{~b}$ 亿対応する外插補間に関する式となる。

一方，ドライ・ベッド水路上での流れの先端条件に関しては，従来から津波あるいはダム破壊問題などを 対象とした多くの先端条件が提案されているが、でてでは岩佐らが氾濫解析で用いたように $\mathrm{h} \leq \varepsilon(\varepsilon=0.001$ $\mathrm{m} ）$ なる地点で段波未到達であると仅定した数值解析上の簡明な条件のみによるとととした。この ととして 用いた数值に関しては明確な根拋が与えられているわけではないが，数值的にはば・流れなし’と考え得る だろらといらてとと，さらに本報告で実施した数值解析上においても段波先端の伝播状況として比較的安定 した結果が得られており，それ汪ど無理な仮定ではないと思われる。

2.3 河道・眝水池采としての洪水追跡の計算スキーム構成

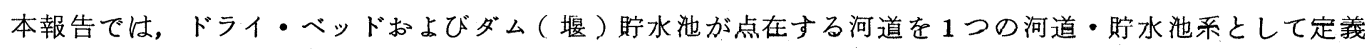
するとととし，その中での洪水追跡を系統的になし得る計算スキームを作成したので，以下にその概略を述 べるととにする。

まず，初期条件に関しては基本的に不等流水面形計算に基づくものとするが，ドライ・ベッド状態の地点 飞おらては不定流計算との整合性から $\mathrm{h}=\boldsymbol{\varepsilon}(\mathrm{Q}=\mathrm{v}=0)$ と仮定する。ドライ・ベッド水路上の不定流計 算に関しては 2.2 節で述べた方法に従うすのとする。をた, 境界条件に関しては水位, 流量あるいは水位〜 
流量関係のいずれ かが一般的に与え

$\mathrm{N}$ : 水路分割数 $(=$ 水路長 $/ \Delta x)$,

られる。

一方, 対象河道 $\mathrm{k}$ : 第k番目の中間ダム, $\mathrm{M}$ : ダムの全個数 格子点 $(D \rightarrow i-1, \quad A \rightarrow i, \quad C \rightarrow i+1$ 番号 $\{\mathrm{B} \rightarrow \mathrm{i}+2, \quad \mathrm{P} \rightarrow \mathrm{i}+\mathrm{N}+1$,

間の途中にダム

(堰)が存在してい る地点における計 算スキームの概略を 示したのが図ー 2 である。ここでは, 通常の境界条件と

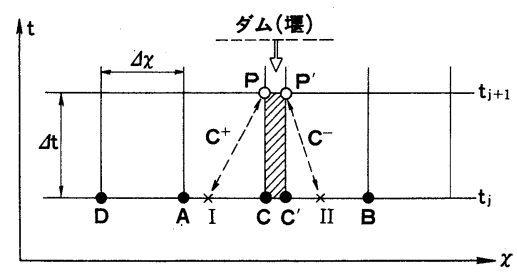

図ー2 ダム地点の計算スキーム しての取扱いが概念上取り入れられる。すなわち, ダム地点 の上流面は下流端としてまた下流面では上流端境界にそれぞ れ対応し，一般的に前者では $\mathrm{H} \sim \mathrm{Q}$ 関係が与えられ，さらにダ ムを越流する際にはその越流量 $\mathrm{Q}$ 用いて後者の計算を行う。

以上のようなととを特に考慮して河道・貯水池系における 洪水追跡を系統的に実行し得るように構成した本解析モデル の計算 flowを示したのが図ー 3 である。

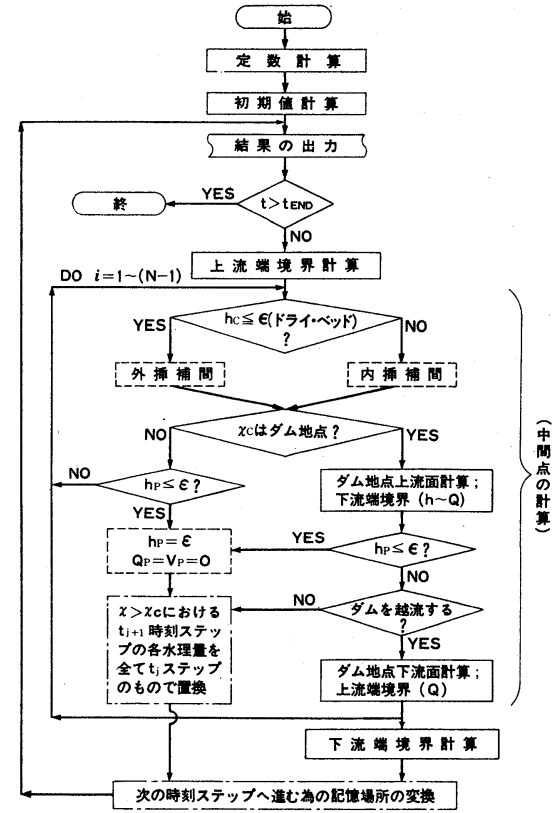

図一 3 本解析モデルの流れ図

\section{3. 実験結果との比較・検討}

\section{1 室内実験の概要}

実験は, 幅 $20 \mathrm{~cm}$, 高さ $40 \mathrm{~cm}$, 長さ $21.4 \mathrm{~m}$, 水路床勾配 $1 / 1000$ のアクリル製矩形水路において数種類の水 路条件を設定して行った。ヘッドタンク内の水位は一定を保つようにされており，また通常の流量調節用バ ルブの外に急開閉バルブを用いて所要の流入流量波形が与えられるよ5にした。水位変化は, 主として 6 地 点に設置した容量式波高計を用いているが, ケースによっては連続写真撮影を併用して測定した。一方, 本 実験の範囲内においてはRe数=7000３0000となっており，ほぼ造移領域に属する流れと判断されるので 一定の抵抗係数を与えるのは必ずしも適当でないが, 8 \% 程度以内の誤差が含をれるてとを前提として背水 計算から推定された Manningの粗度係数の平均值 $\mathrm{n}=0.0081$ を採用するととにした。

\section{2 ドライ・ベッド水路上の段波}

まず，図ー4 はドライ・ベッド水路上における段波先端の伝播特性に関する実験結果の 1 例を示したもの である。流量立上り時間の差異による段波到達の時間差は(ii)〜(iii)断面までにほぼ決定され，その下流側では同 程度の伝播速度 $\omega \doteqdot 1.4 \mathrm{~m} / \mathrm{s}$ で等流々速の 2 倍以上の 大きさとなっている。一方, 眓一 $5 \mathrm{a}$ は $\mathrm{A}-1$ のケース について水位変化の実験值とシミュレーション結果と の比較を示したものである。実験值と比較して計算值 の方が伝播速度は小さいょらであるが, 上述の粗度係 数の誤差範囲に見合ら程度の差であり, 㴗良好な適 用性が得られたと考える。ただし，下流端境界条件と しては $\mathrm{x}=19.4 \mathrm{~m}$ 地点における $\mathrm{H} \sim \mathrm{Q}$ 関係を与えた。

3.3 貯水池内における段波

水路下流端 $(\mathrm{x}=21.4 \mathrm{~m})$ 地点に高さ $11 \mathrm{~cm}$ の堰板 を設置した上で，その中に静水を満杯状態にして模擬

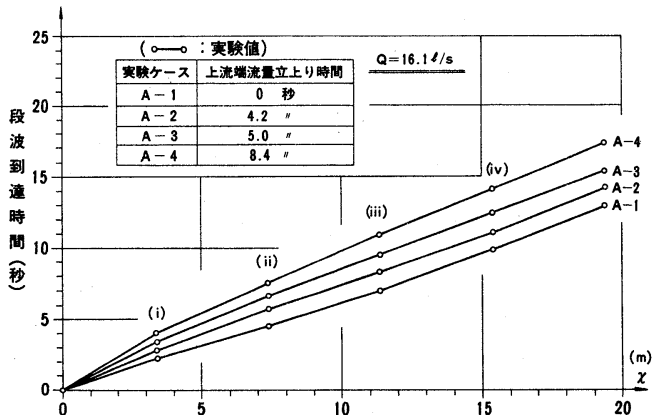

図ー4 段波到達時間( ドライ・ベッド) 
された貯水池内における段波の実験值と計算值を比較

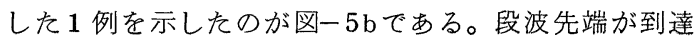
してから,さら反水路下流端の堰からの反射波が上流 側に伝わって行く様子などが比較的よく再現されてい るものの, 反射波の大をさが計算值の方では過小評価 される傾向が示されている。一方，ての場合の実験で は, 初期水梁が相対的に大をいので上流端の流量立上 り時間の影響を受けるのは上流側のみであって, 完全 に発達した段波先端を形成するのが比較的早くなって いる。そとで, 従来の理想段波としての取扱い ${ }^{9)}$

$$
\omega=\mathrm{v}_{1}+\sqrt{\mathrm{gh}_{1}}\left\{\frac{\mathrm{h}_{2}}{2 \mathrm{~h}_{1}}\left(\frac{\mathrm{h}_{2}}{\mathrm{~h}_{1}}+1\right)\right\}^{1 / 2}
$$

（添字 1,2 はをそれぞれ段波到達前後を示す。）

に上る検討を行ったとてろ, 下流方向への初期水潹の 增加に伴ら段波伝播速度の増大傾向などが実験値とか なり良好な一致をしている結果も得られた。

3.4 ドライ・ベッド〜眝水池に打ける段波

ドライ・ベッドから貯水池に変化している水路にお ける段波の変形に関して実験值と計算值を比較したも のが図一 $5 c$ である( 水路形状に関しては図ー6を参照 されたい)。(i)は上流側のドライ・ベッドに，また(ii) 〜 ( V V は眝水池の初期条件飞対応する地点である。貯水 池流入部付近飞相当する (ii) (iii)の地点飞おいて段波 到達後の初期段階での波形は実験值よりも計算值の方 が大きくかつ早目に伝播しているが，その前後では比 較的よく一致した結果を示している。ての場合におい ては, 眝水池流入值後の(ii)地点までの段波先端速度は その上流のドライ・ベッド水路における伝播速度の約 $1 / 2$ 飞減少しており, それから(iii)地点をでの初期水 梁增加区間でその半分程度の速度が回復し,さらにダ ム (落差) 地点の越流時飞若干また減少するよらな傾 向が示された。この中で特に, 最初の貯水池流入部近 傍における伝播速度の減少に関しては, 段波流入水の 運動量拡散による水クッション的な効果が大をく作用 しているものと思われる。一方, ての場合の $\mathrm{x}>13 \mathrm{~m}$
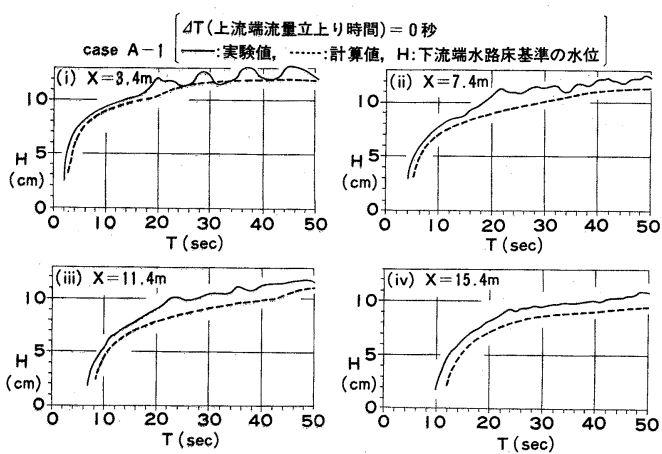

(a)ドライ・ベッド $(\mathrm{A}-1): \mathrm{Q}=16.1 \mathrm{l} / \mathrm{s}$
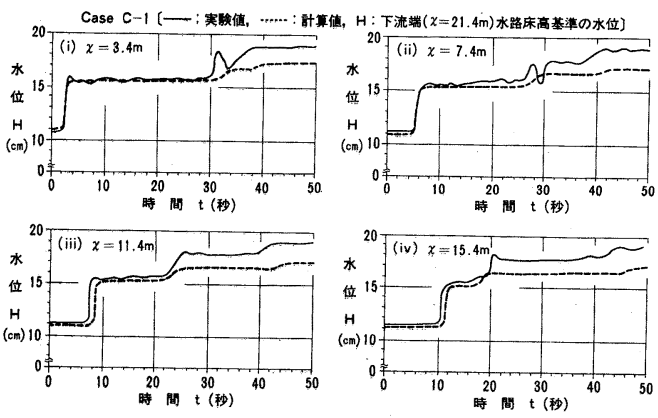

(b) 貯水池内 $(\mathrm{C}-1): \mathrm{Q}=11.6 \mathrm{l} / \mathrm{s}$
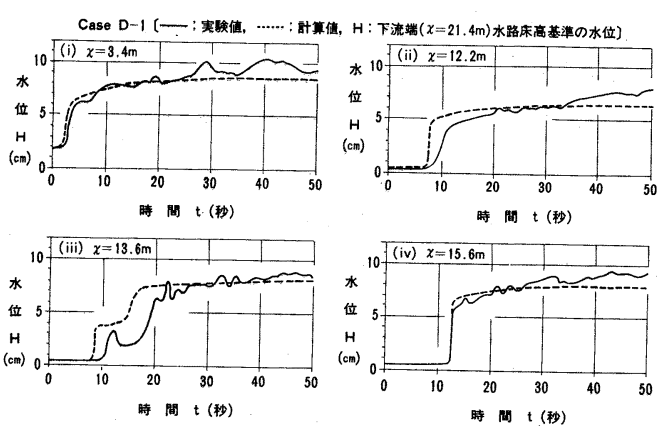

(c) ドライ・ベッド〜貯水池 $(\mathrm{D}-1): \mathrm{Q}=9.7 \ell / \mathrm{s}$

図-5 実験值と計算値の比較 (水位変化) の貯水池区間《和いては跳水と見 られる現象が生じており, 図一6 ではそれが顕著に示されている。 本解析モデルイおいては，常流と 射流が混在する場合にす対応し得 る特性曲線網の整斉手法を用いて らるので,てのような場合に対し

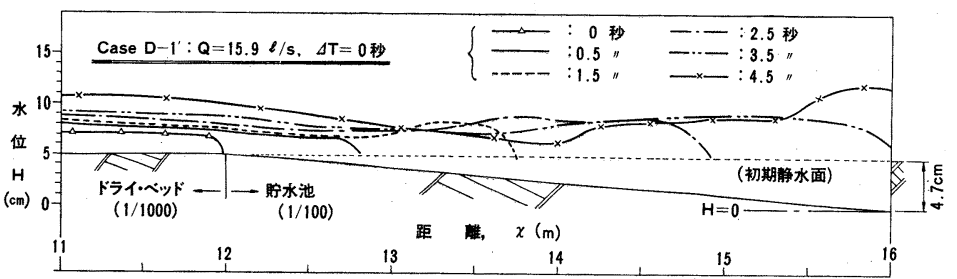

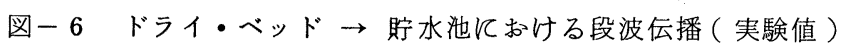




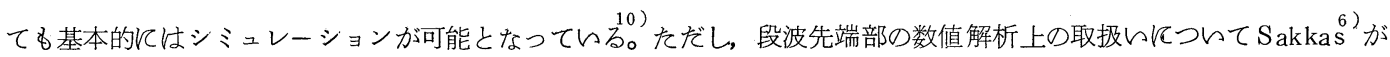
述べているように，数值計算の不安定さを避ける意味から時間ステップ $\Delta \mathrm{t}$ を通常より小さ目にとるなどの考慮も場合 によっては必要であろら。また，乙の場合に関しては特に，眝水池を模擬するために設けた水路の段差が小 さく十分な貯水池モデルとなっていないので定量的な評価に関しては議論の余地があると思われる。

\section{4. 実河川への適用}

本解析モデルの適用性に関しては，上述の室内実験結果との比較・検討などによりほぼ妥当な精度を有す ることが確認されたが，さらに実際の河川におけるドライ・ベッド水路上の段波実験かよび河道・貯水池采 での出水に対して適用した結果につけて以下に述べる。

4.1 ドライ・ベッド水路上の段波

昭和 56 年 4 月 23 日飞北海道電 力・真勲別発電所余水路の放流実験 を実施した際に減勢工出口から本川 (石狩川水系・陸満別川) 飞合流寸 るまでのドライ・ベッドの自然河床 上飞おける放流水段波の伝播現象を 観察した。対象とした水路の区間長 は約 $60 m$ であり，5 地点で与えられ ている断面図より解析上の等価台形 断面飞変換した。河床勾配は上流端 上り $\mathrm{x}=55 m$ まで $1 / 35$ から $1 / 75$ へと少し緩かになるが, $\mathrm{x}>55 m$ で は $1 / 10$ と急である。また，河床幅 は約 $7 \mathrm{~m}$ ，水路側壁勾配飞ついては

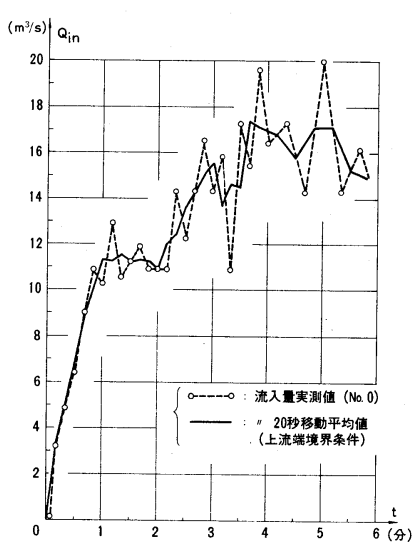

図一 7 放流量( 上流端 $)$ $\delta=2.5$ のそれぞれ近傍の值となっている。粗度係数については河床 状況から $\mathrm{n}=0.045$ を推定值として与えた。図ー 7 は放流工出口の 堰越流水位から換算して求めた上流端境界条件としての流量変化で

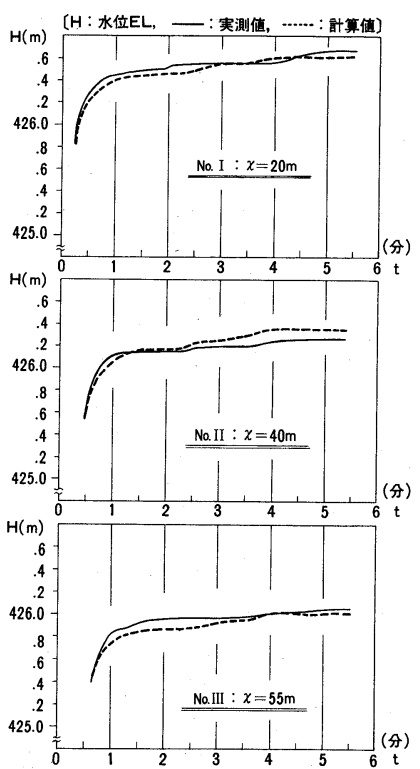

図一 8 水位変化 ある。距離ステップ $\Delta \mathrm{x}=2.5 \mathrm{~m}$ で計算した結果の水位変化と段波 伝播速度に関して，実駼值との比較を図一8和よび図ー9亿それ ぞれ示した。データとして与えられている断面定数等がどちらかと 言えば粗い割には，かなり良好な再現性が得られている。衣た，段 波先端の近傍においては 1 よりやや大をなフルード数の状態で伝播 30 しており,さらに $\mathrm{x}=55 \mathrm{~m}$ 前後より下流ておいては段波到達後の 流れが常に射流状態であるととが計算結果として示された。

4.2 河道・貯水池系飞打りる段波

河道・眝水池系の 1 例として図一 10 亿示すよらな延長約 $31 \mathrm{~km}$ の $\mathrm{T}$ 河川飞適用した結果を述へる。至の解析対象領域は, 与えられて いる諸条件から表一1のよらな領域区分がなされるが，てのらち(II) と田の区間においては河川改修が進んでいる。またての河川区間 の中には多数のダム, 落差工が点在しており, 一連の河道・貯水

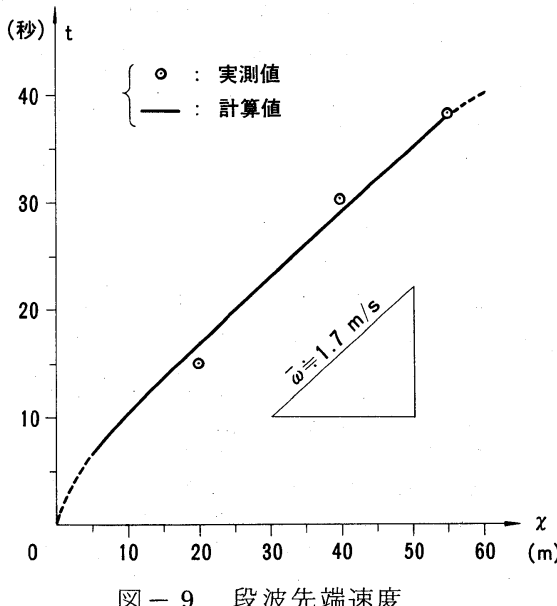

図一 9 段波先端速度 池系を形成している。シミュレーションは, 昭和 52 年 8 月の既往出水を模擬して, 上流の $\mathrm{T}$ ダムから瞬間的に $290 \mathrm{~m}^{3} / \mathrm{s}$ が放流された (その後は一定) 場合を想定し, さらに初期条件としてダム・落差工による貯水が有る区間 
以外はドライ・ベ

ッドとした場合と,

平水流量が流れて

らる場合の 2 ケー

スについて計算を

行った。初

期条件飞関

しては，夏

季の当該河

川でドライ・

ベッド状態

の区間が一

般的に多い

ことを考虑

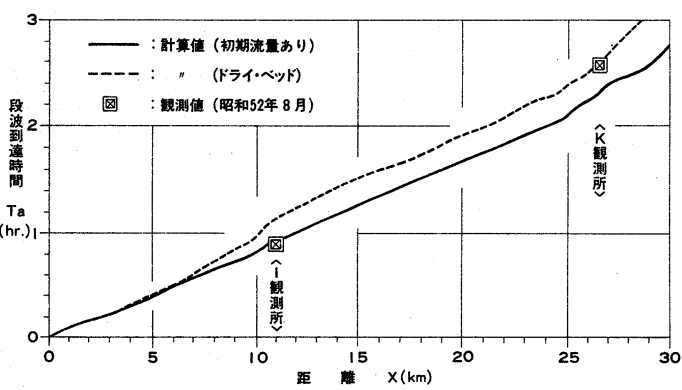

図-11 段波到達時間

したすのである。図ー 11 と図一 12 はとの結果得られた段波到達時

間と最大上昇水位であり，比較的良好な再現性が得られている。

この場合の伝播速度に関しては, 河床勾配の影響が大をく寄与し,

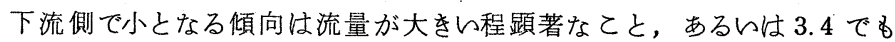
述べをよらにダム越流時に多少遅れる特性が認められた。一方, 偠

一様な形状とみなせる $17 \mathrm{~km}<\mathrm{X}<20 \mathrm{~km}$ 区間におけるドライ・ベッド水 路として解析した数ヶースの流量に対する段波先端速度の結果は, 各 対象流量の等流々速にかなり近い值として得られた。

\section{5. あとがき}

ドライ・ベッド水路やダムなどが点在する河道・貯水池系に対しても洪水 追跡を合理的に実行する為に, 特性曲線法に基づく解析モデルを新をに作成 し，その良好な適用性を得ることがでさた。今後，洪水警報体制の確立などに 資するために,さらに有用な解析モデルに発展させたいと考えている。

最後に、現地実験等については北海道電力株式会社土木部水路課の 多大なる卸協力を載いた。乙てに記して, 関係各位に心ょりの謝意を 表する次第である。

\section{参 考 文 献}

1) 荻原能男 : 流出現象の非定常解析, 土木学会水工学シリーズ, 7 7-A-3, pp.A. 3.1-A.3.14, $1977-7$.

2) 河西基, 白砂孝夫, 五十嵐由雄 : 特性曲線法によるドライ・ベッド水路上の段波伝播解析, 第 37 回土木学会年講, pp.275-276, $1982-10$.

3) 玉井信行, 河西基 : 河道狭窄部が洪水波形飞及经す影響について, 第 22 回水理講演会論交集, pp. 239-244，1978-2.

4) 荻原能男, 河西基 : 斜面流出における非線形効果に関する一考察, 山梨大学工学部研究報告, Vol.27,pp.62-67, 1976.

5) 松富英夫：ドライ・ベッド上のダム破壊流れの数值解析, 第 26 回水理講演会論文集, pp 409-416, 1982-2.

6) Sakkas, J.G.and Strelkoff, T. : Dam - Break Flood in a Prismatic Dry Channel, Proc. of ASCE, Vol.99, HY 12, pp.2195-2216, $1973-12$.

7) 後藤智明, 首藤伸夫 : 各種津波遡上計算法と波先端条件の比較, 第 27 回海岸工学講演会論文集, pp. 80-84, 1980.

8) 岩佐義朗, 井 和也 : 氾濫水の水理の数値解析モデル (その 2 ), 第 17 回自然災害科学総合シンポジム, pp. 241-244, $1980-10$.

9) 例えば, 荒木正夫，椿東一郎：水理学演習 (下)，森北出版，pp. 93-97，1962.

10) Kawanihi, M.and Tamai, N.: On the Deformation of Floods due to Bottle-Neck Valleys, International Conference on Water Resources Eng ineering, Bangkok, Tha iland, 1978-1.
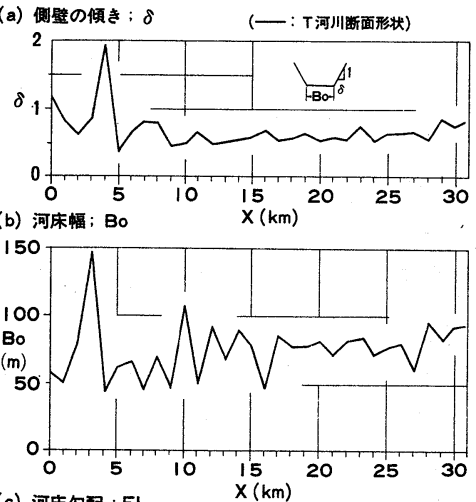

c) 河床勾配 ; EL.

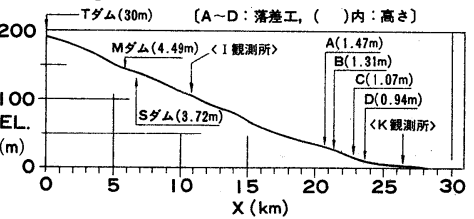

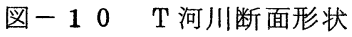

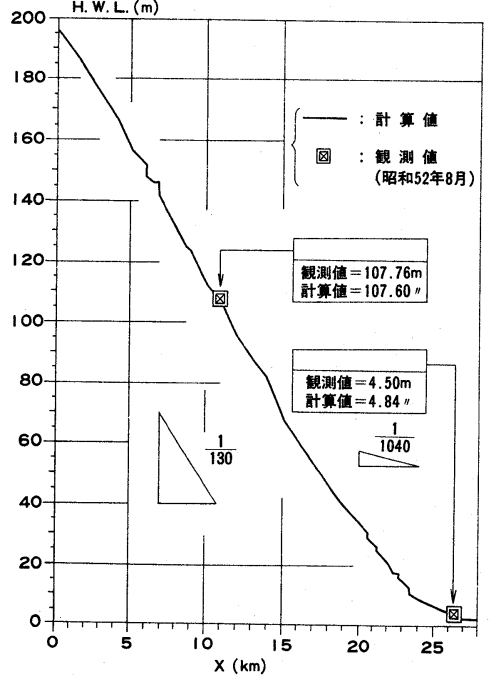

図一 12 最大上昇水位 